\title{
A DESPOLITIZAÇÃO DA DEMOCRACIA LIBERAL NO PENSAMENTO DE CARL SCHMITT*
}

\section{Pedro Villas Bôas}

\section{Introdução}

A investigação de premissas da despolitização provocada pela democracia liberal abre caminho para a reflexão sobre a coexistência dos fundamentos do liberalismo e da democracia. A origem das tensões existentes entre liberdade e igualdade, autonomia e heteronomia, razão pública e razão privada podem ser pensadas à luz da distinção entre o foro íntimo e foro externo, alcançada por meio do processo de secularização. Carl Schmitt (1888-1985) expõe em diversos trabalhos a incompatibilidade da identidade pretensamente existente entre democracia e liberalismo, sobretudo a partir do surgimento

* Agradeço aos pareceristas anônimos da RBCS pela contribuição à versão final deste artigo.

Artigo recebido em 04/01/2010

Aprovado em 28/06/2011 no século XIX da democracia de massas. Todavia, as primícias de tais tensões já podem ser observadas a partir de sua abordagem de dois sentidos distintos do conceito de secularização: o de secularismo de cunho iluminista e a secularização com o sentido de emancipação e inteligibilidade do político.

A proposta deste estudo é percorrer alguns trabalhos de Schmitt a fim de mostrar que o tratamento conferido pelo autor ao conceito de secularização é indispensável para compreender as origens do processo de despolitização conduzido pela democracia liberal. A despolitização suscitada pelos conceitos da democracia liberal pressupõe a compreensão da conhecida fórmula schmittiana segundo a qual todos os conceitos relevantes da teoria do Estado moderno seriam conceitos teológicos secularizados.

$\mathrm{Na}$ primeira parte do trabalho, investigo o sentido atribuído por Schmitt à secularização de conceitos teológicos e sua relação com a despolitização da democracia liberal. Na segunda parte, abordo o tema 
da secularização do político por meio do desvelamento dos antagonismos existenciais ocultados pelo fundamento dos conceitos democráticos liberais. $\mathrm{Na}$ terceira, procedo à discussão do grau de intensidade do político e sua relação com a despolitização provocada pela democracia liberal. Vale a pena mencionar que o conceito de secularização é utilizado como categoria heurística capaz de revelar a tensão entre a visibilidade do político e sua invisibilidade promovida pelo pensamento liberal e positivista.

\section{O político pressupõe a secularização dos conceitos teológicos}

Schmitt, no livro Politische Theologie, apresenta o conceito de secularização com dois sentidos: um histórico e outro hermenêutico. O sentido histórico ${ }^{1}$ busca reconduzir os conceitos do Estado moderno ao seu caráter polêmico, observado em distintos contextos de luta política, por meio dos quais o conceito de secularização amplia sua extensão semântica. Além de esse conceito adquirir diferentes acepções polêmicas no curso do desenvolvimento histórico, contém um caráter hermenêutico por meio do qual seria possível desvendar a estrutura metafísica da realidade. Para Schmitt, toda realidade histórica, assim como toda concepção do mundo, tem um núcleo metafísico que corresponde a uma última instância, a um centro absoluto (Schmitt, 1998, p.17). A formulação de Schmitt revela que:

[...] todos os conceitos marcantes da teoria do Estado moderno são conceitos teológicos secularizados. Isso vale tanto para o seu desenvolvimento histórico, já que foram transferidos da teologia para a teoria do Estado, transformando-se, por exemplo, o Deus todo-poderoso no legislador onipotente, como para sua estrutura sistemática, cujo conhecimento é necessário para uma consideração sociológica dos conceitos (Schmitt, 2004, p. 43). ${ }^{2}$

O enunciado acima é uma resposta às doutrinas do Estado moderno que visam privá-lo de seu conceito de soberania. A suposta origem teológi- ca dos conceitos políticos e jurídicos da teoria do Estado moderno poderia ser demonstrada de dois modos: o primeiro seria indicado pelo decurso histórico mediante o qual se observa uma transferência da esfera teológica a uma esfera política. A transformação de um Deus todo-poderoso num legislador onipotente seria um exemplo dessa transferência.

O segundo sentido, de cunho hermenêutico, mostra uma afinidade estrutural que pode ser observada através de uma analogia entre conceitos teológicos e políticos. $\mathrm{O}$ exame desta afinidade estrutural entre a teologia e a política torna inteligível o fato de ambas as áreas do conhecimento compartilharem de uma estrutura comum: a imagem metafísica do mundo. Para Schmitt, todo pensamento inclui um comportamento metafísico diante do mundo, observado em representações e projeções de imagens. Com isso, o jurista pretende tornar explícito que o processo de secularização, a despeito de afastar representaçôes e imagens sagradas do mundo, não significa a perda de uma atitude metafísica:

[...] existem hoje muitos tipos de atitude metafísica em forma secularizada. Para o homem moderno, em grande medida, surgiram no lugar de Deus outros fatores e, precisamente, fatores terrenos: a humanidade, a nação, o indivíduo, o desenvolvimento histórico [...]. A atitude não deixa com isso de ser metafísica. O pensamento e o sentimento de cada homem conservam sempre um determinado caráter metafísico; a metafísica é algo inevitável e [...] não se pode lhe escapar renunciando a se tornar consciente dela (Schmitt, 1998, p.18).

Nenhuma realidade histórica poderia libertar-se de um núcleo metafísico. A secularização assume aqui o sentido de substituição e não de transferência. Diz respeito à substituição da posição ocupada por Deus por fatores terrenos, o que não implica o desaparecimento de uma raiz metafísica. Toda projeção de imagem compartilha com a realidade política e social uma estrutura metafísica comum. Tanto a realidade histórica como uma concepção de mundo apresentam uma imagem metafísica fundada num fator último de legitimidade, seja ele representado por um elemento divino ou 
terreno. A realidade histórica e a imagem de mundo estruturam-se a partir de um centro ou de uma instância absoluta que podem ser substituídos por outros elementos:

[...] certamente, porém, aquilo que os homens consideram como instância absoluta última pode mudar, e Deus pode ser substituído por fatores terrenos deste mundo. É a isso que chamo secularização, e é sobre isso que falo e não sobre aqueles casos também muito significativos, mas em comparação com esses, são casos superficiais (Idem, ibidem).

A secularização consiste numa substituição de imagens cuja dissolução de representações tradicionais não implica na eliminação de um fundamento metafísico. De um lado, o surgimento do Estado moderno e seus conceitos jurídicos e políticos resultam de um processo de secularização compreendido a partir da neutralização dos conflitos religiosos dos séculos XVI e XVII. De outro, a secularização é apresentada como uma sucessiva substituição de imagens metafísicas. Em outras palavras, a secularização revela que a realidade, apesar das suas mutações históricas, conserva uma estrutura na qual haveria uma instância absoluta constantemente substituída de acordo com distintas imagens ou concepçôes de mundo. Desse ponto vista, a estrutura ontológica da realidade seria formada pelas representações do mundo que ocupam uma posição central. Posto de outra forma: as qualidades da realidade são conformadas pelas projeções de crenças que alcançam um lugar central ou "ponto último de legitimidade” para suas representações. No século XVII, o Deus teísta da realidade segura da velha metafísica havia sido destronado e para o conceito de secularização concebido por Schmitt

[...] mais importante do que a controvérsia dos filósofos era a questão de quem assumiu sua função como realidade mais segura e elevada e, assim, como último ponto de legitimidade na realidade histórica. Duas novas realidades surgiram neste mundo e impuseram uma nova ontologia sem esperar pelo fim da discussão da teoria do conhecimento: a humanidade e a his- tória. Completamente irracionais, se as observarmos pela lógica da filosofia racionalista do século XVII, mas objetivas e evidentes na sua configuração supraindividual, elas dominaram in realitate o pensar da humanidade como dois novos demiurgos (Idem, p. 68).

A sucessiva reocupação da posição central por distintas imagens de mundo encontra sua dinâmica nos conflitos travados entre homens, como se observa na Revolução Francesa inspirada pelos ideais universais do iluminismo. As representações de uma imagem universal da humanidade e de uma história geral orientada para o progresso retiravam sua pujança de uma concepção metafísica do mundo. A substituição de Deus pelas representações imanentistas de humanidade e história não eliminaria o resíduo teológico ou metafísico, pois a toda época é subjacente um núcleo metafísico. Assim, mesmo destronando o Deus pessoal teísta, a humanidade e a história continuariam exercendo um papel demiúrgico. Dominados por tais crenças, os homens, como seria o caso dos jacobinos, seriam arrebatados pelo fanatismo, e as lutas revolucionárias assumiriam um sentido religioso. Comenta Schmitt que em face do espírito revolucionário jacobino a

[...] política se torna um assunto religioso, o órgão político um sacerdote da república, da lei, da pátria. Contra todo dissidente político, toda opinião desviante, o jacobinismo se enfurecia com fervor sanguinário. Seu fanatismo tinha caráter religioso, o novo culto da liberdade, a virtude ou o "ser supremo" era uma consequência natural. [Da perspectiva dessa religião imanentista] todo inimigo político [...] era um "ateu" (Idem, p.69).

Mediante o conceito de secularização é possível compreender o fenômeno da despolitização e da neutralização das doutrinas do Estado moderno como é o caso da concepção de um Estado fundado nos princípios da democracia liberal - dos séculos XIX e XX, que buscavam privar o Estado de seu sentido político. Conforme Schmitt, a despolitização das doutrinas do Estado moderno ocorreria por meio da tentativa de substituir o sentido político 
da soberania por "representações de imanência" (Schmitt, 2004, p. 53). Através do exame da concepção que uma época faz do mundo seria possível conhecer a sua forma de organização política, e a elaboração de seus conceitos correspondentes, pois "a imagem metafísica que uma determinada época faz do mundo tem a mesma estrutura daquilo que lhe parece evidente como forma de sua organização política” (Idem, p. 50).

A secularização revelaria uma sucessão de representações de imanência manifestadas por meio de noçôes como autogoverno, autofuncionamento, autorregulamentação. A realidade estaria dominada por imagens de mundo na qual as açōes políticas, a realização do direito, a soberania e a decisão política tornam-se supérfluas, pois o mundo funcionaria por si mesmo, se autorregulamentaria. Nas representaçôes de imanência as ações políticas são inócuas, pois o mundo político, social e econômico funciona por si mesmo, possui um motor próprio. Em tais representações, como é caso da liberal, "espera-se que a vida pública se governe a si mesma” (Schmitt, 1984, p. 47). Às concepções de imanência, evidenciadas pela analogia entre teologia e política, seriam comuns emanações, panteísmos e o deísmo, cuja expressão pode ser encontrada sob a forma da mão invisível reguladora do mercado no lugar de ações humanas, e o governo das leis econômicas no lugar de decisões políticas soberanas. Assim, "nem os homens tampouco as coisas necessitam 'governo' quando se abandona o mecanismo do econômico e do técnico à sua regularidade imanente" (Idem, p. 60).

$\mathrm{Na}$ Politische Theologie, o sentido do conceito de secularização de Schmitt surge de forma contrária à acepção iluminista da secularização. A secularização iluminista, também denominada secularis$m o,{ }^{3}$ procede - segundo a concepção do jurista - à substituição de representaçôes de transcendência por representações de imanência. Essa substituição teria o escopo de eliminar a contingência da vida humana. Ora, para Schmitt é justamente na inteligibilidade e na percepção da contingência que se descortina a responsabilidade do agir e decidir político no mundo. O propósito de seu conceito de secularização é desvelar tais representações de imanência e exibir seus demiurgos. O desvelamen- to dos sujeitos que ocupam o centro absoluto, estruturante da realidade, encontra sua maior expressão no indivíduo burguês "apolítico", na filosofia da história voltada para o progresso e na noção universalista de humanidade (Schmitt, 1998, p.78). Schmitt, nos trabalhos Politische Theologie e Der Begriff des Politischen, busca mostrar que o político é irredutível à dimensão de imanência que exclui a contingência a fim de se constituir em um sistema de funcionamento autônomo. A irredutibilidade do político revela-se no seu caráter transcendente, ${ }^{4}$ que descortina uma filosofia da vida cuja concepção existencialista escapa a qualquer normatividade positivista ou liberal. Schmitt, em Gesetz und Urteil de 1912, já havia transformado a contingência ou ruptura no princípio epistemológico de sua investigação, demonstrando a necessidade de uma decisão para determinação do direito. Na Politische Theologie, a contingência ou ruptura assume a ideia de exceção como ferramenta epistemológica capaz de minar concepções racionalistas imanentistas, que tomam a normalidade do ordenamento jurídico e o autofuncionamento da vida social como harmonia preestabelecida. Conforme o jurista,

[...] a exceção é mais interessante do que o caso normal. O caso normal não prova nada, a exceção prova tudo; ela não só confirma a regra como é a própria regra que vive tão-somente da exceção. $\mathrm{Na}$ exceção a força da vida real irrompe da crosta de uma mecânica enrijecida na repetição. Um teólogo protestante que demonstrou de que intensidade vital a reflexão teológica também podia ser capaz no século XIX disse (Carl Schmitt, 2004, p. 21): "A exceção explica o geral e a si mesma. E se porventura se quiser estudar corretamente o geral basta procurar uma exceção real. Ela põe tudo mais às claras do que o próprio geral. Com o tempo fica-se farto desse eterno falatório do geral; exceções existem. Se não se pode explicá-las, então também não se pode explicar o geral. Habitualmente não se repara na dificuldade, pois se pensa o geral não com paixão, mas com cômoda superficialidade. A exceção, pelo contrário, pensa o geral com enérgica paixão" (Kierkegaard apud Schmitt, 2004, p. 21).5 
Os sujeitos e os conceitos que ocupam e desempenham a antiga função do Deus pessoal teísta da velha metafísica, como o indivíduo burguês, a filosofia progressista ou conceito universalista de humanidade são incapazes de lidar com os casos-limite ou situaçôes críticas, pois a racionalidade normativa das leis gerais não prevê tais situações. $\mathrm{O}$ grande problema que percorre boa parte dos trabalhos de Schmitt se revela na luta contra a negação da contingência que, como disse, assume um sentido mais específico na Politische Theologie. No referido trabalho, o jurista admoesta: "o racionalismo do esclarecimento recusou a exceção de toda forma" (Schmitt, 2004, p. 43). Creio que seja fundamental ter em vista que o esforço liberal e positivista para varrer a contingência, precisamente a exceção para fora do mundo, corresponde à eliminação do núcleo político fundamental compreendido pelo conceito de soberania. Por isso, o jurista o define como "conceito-limite" (Grenzbegriff). O caso de exceção ou da contingência extrema é a situação extraordinária na qual se revela o ponto mais alto do político: a soberania.

Da perspectiva de Schmitt, o "conceito-limite não significa um conceito confuso como na terminologia obscura da literatura popular, mas um conceito da esfera extrema. A isso corresponde o fato de que sua definição não pode se vincular ao caso normal, mas a um caso-limite" (Idem, p. 13). O caso-limite da guerra, por exemplo, revelaria o jus belli ou o direito de dispor sobre a vida dos membros da associação política (Schmitt, 2002b, p. 46). $\mathrm{Na}$ normalidade, no funcionamento regular do ordenamento jurídico, a soberania é invisível, mas no caso-limite ou crítico se revelaria a própria estrutura da realidade e a essência do direito proveniente de uma decisão. Todavia, a partir do iluminismo surge uma imagem deísta de mundo cuja identidade estrutural é encontrada no Estado de direito liberal, que não tolera nenhuma espécie de exceção ou rompimento das leis imanentes à natureza:

[...] a ideia do moderno Estado de direito se impõe com o deísmo, com uma teologia e metafísica, que bane o milagre do mundo e recusa o rompimento das leis naturais, contido no conceito de milagre, que estabelece uma exceção por meio de uma intervenção imediata, do mesmo modo recusa a intervenção imediata do soberano numa ordem jurídica vigente (Schmitt, 2004, p.43).

A teologia ou a metafísica deísta "que bane o milagre do mundo" e não admite a ruptura de leis naturais encontra sua analogia ou correspondência no Estado de direito que nega a soberania que decide sobre a exceção a fim de intervir na realidade. A soberania transcendente quebra a regularidade imanente à normalidade das leis do Estado de direito da mesma forma que o milagre interrompe o ordenamento natural das coisas. Exceção, decisão e intervenção apresentam uma afinidade estrutural com a ideia de um Deus transcendente que se posiciona acima do mundo, assim como a pessoa do soberano sobrepóe-se ao Estado (Idem, p. 53). A substituição de representações de transcendência por concepções de imanência não teria no âmbito da teoria do direito e do Estado deixado de lado um núcleo metafísico que conferia caráter sagrado à lei ou à vontade do legislador, no século XIX, dominado pela cultura positivista, precisamente pelo positivismo jurídico. Segundo Carl Schmitt, a dinâmica das lutas e a imposição de ideais levaram à substituição de um Deus teísta pelo Deus deísta. ${ }^{6}$ Em outras palavras, a substituição de representaçôes de transcendência por representações de imanência implica a invisibilidade ou a ininteligibilidade do poder político cuja desontologização ${ }^{7}$ o reduz à impessoalidade normativa do dever ser. Assim, o poder político outrora encarnado num soberano pessoal passa a ter a forma abstrata da lei, mas o governo da lei não substitui o governo dos homens, pois homens concretos continuam governando homens concretos por trás da fachada da lei. As representaçôes de imanência apresentariam um paralelismo com a forma de organização política que se empenha em substituir o pessoal pelo impessoal, o subjetivo pelo objetivo, a exceção pela normalidade, enfim negam o político. Desse modo, a complexa realidade política e social é subsumida à uniformidade e à regularidade de uma ordem imanente ao mundo. Ao retratar o espírito romântico, cujo portador seria a burguesia liberal, Schmitt apresenta uma interessante imagem do que poderia ocorrer com as representaçôes 
de imanência do mundo do normativismo liberal e do positivismo que, ao negar a decisão, eleva as oportunidades. A ampliação das oportunidades sem o fator indispensável da decisão pela sua redução não significa outra coisa senão a elevação dos níveis de contingência: "a partir de oportunidades sempre novas surge um mundo sempre novo, mas sempre só ocasional, um mundo sem substância e ligação, sem condução firme, sem um último tribunal, que segue em diante infinitamente conduzido apenas pela mão mágica do acaso, the magic hand of chance" (Schmitt, 1998, p. 19).

$\mathrm{Na}$ visão de Schmitt a tentativa de negar ou ocultar o político, com seu caráter transcendente pessoal e soberano, poderia sujeitar os homens à condução da mão mágica da contingência. No eclipsamento do político, a secularização revela seu sentido de imanência tornando invisível a contingência. Este sentido também é observado por Niklas Luhmann (1927-1998) ao salientar que "com a secularização é finalmente registrada a invisibilidade da mão de Deus e da noção 'le monde va de lui-même” (Luhmann, 2002, p. 285). O empenho da democracia liberal em recalcar o político não elimina o exercício do poder político e tampouco a produção de seus efeitos. Todavia, da perspectiva de Schmitt, a tentativa de escamotear seu caráter transcendente e pessoal o relega ao plano secreto, tornando-o invisível e, portanto, espúrio. O problema da negação do político é que nos bastidores o poder não deixa de ser exercido e concentrado na mão de poucos homens que com "maldade suprema dirigem a história dos homens de forma invisível [...] por meio da crença secularizada numa providência”. A crença na salvação imanente a fatores terrenos, como a história, leva Schmitt a dizer: "estamos desamparados na mão do poder que joga conosco" (Schmitt, 1998, p. 88). O velamento ou a invisibilidade do político traduz-se na vitória da fortuna sobre a ação política decisória, no triunfo da imprevisibilidade sobre a previsibilidade.

\section{A secularização do político}

A fim de compreender o empenho de Schmitt em promover a secularização do conceito do po- lítico é imprescindível analisar como o jurista interpreta e retoma algumas ideias de Thomas Hobbes (1588-1679). Ninguém percebera melhor do que Hobbes "que conceitos e distinções são armas políticas, e, precisamente, dos poderes "indiretos" (Schmitt, 2003a, p. 26). O caráter político do poder "indireto" se tornaria patente nas oposições concretas dadas pela realidade de uma situação-limite como seria o caso da guerra civil-religiosa. O filósofo inglês teria tornado claro que toda controvérsia entre o espiritual e o temporal se converte numa disputa política, na medida em que se torna uma questão existencial que só poderia ser decidida por quem tem o monopólio da decisão. A observância dessa questão existencial, identificada numa situação extrema de luta pela conservação da vida, permitira distinguir um sentido eminentemente político de outros conteúdos que o teriam desencadeado. Schmitt acredita retirar de Hobbes o conhecimento de que a luta travada entre homens pode extrair seu fundamento nas mais diversas áreas de conteúdo. Todavia, se a luta atingisse um nível mais elevado, ela se tornaria existencial e, justamente aí, no grau mais extremo de sua medida, assumiria uma tensão especificamente política. Tal tensão se torna nítida a partir da possibilidade da negação ontológica recíproca entre agrupamentos humanos, que pode sempre ocorrer a partir de uma situação extrema que escapa a qualquer previsibilidade normativa.

A interpretação que Schmitt faz de algumas ideias de Hobbes é da maior importância para compreender a secularização do conceito do político que o jurista não só pensa ter se iniciado com Hobbes, mas considera necessário dar continuidade. A referida interpretação mostra que a extrapolação do grau extremo alcançado pelo político, isto é, pelos dos antagonismos humanos, no cenário das guerras civis-religiosas extrairia sua intensidade dos poderes espirituais, precisamente de suas argumentações teológico-morais. Schmitt concorda com Hobbes que o político, compreendido como dimensão existencial do conflito, deve ser alijado dos fundamentos teológicos que tornariam os antagonismos exorbitantes, impossibilitando a distinção entre amigo e inimigo. $\mathrm{O}$ véu teológico-moral encobre o sentido político existencial e, por este motivo, cabe proceder ao seu desvelamento secularizante a fim de reconhe- 
cer o conflito entre agrupamentos humanos como algo pertencente à esfera existencial e não ao âmbito teológico, divino ou moral que estigmatiza e criminaliza o inimigo. Aqui é necessário apontar uma dificuldade que pode surgir com relação à compreensão do conceito de secularização de Schmitt. A despeito de o autor constatar uma relação metódica ou formal entre teologia e política, opõe-se veementemente ao fundamento moral ou teológico-moral de conceitos políticos. O fundamento teológico-moral oculta o político com suas tendências normativas e generalizantes, abstraindo do caráter existencial e contingencial do político. Isso significa que o político e seus conceitos, entendidos a partir da contingência máxima representada pelo conflito, se eleva exageradamente - ultrapassando a medida tolerável de risco - quando os conflitos são velados. Em virtude das razôes apresentadas, Schmitt esclarece que

[...] a relação metódica de pressupostos do pensamento político e teológico é, portanto, clara. Porém, o apoio teológico frequentemente confunde os conceitos políticos, porque comumente desloca as distinçôes para o teológico-moral, ou no mínimo se mistura com isso, e então na maioria das vezes um ficcionalismo normativo obscurece ou mesmo um oportunismo prático-pedagógico obscurece o conhecimento dos antagonismos existenciais (Schmitt, 2002b, p. 64).

A passagem revela que se, de um lado, Schmitt reconhece uma relação formal ou metódica entre premissas teológicas e políticas, de outro, o político e seus conceitos devem ser secularizados ou distinguidos do ficcionalismo normativo da moral-teológica que escamoteia o caráter existencial dos antagonismos. É imprescindível notar que o sentido do conceito de secularização empregado por Schmitt pretende separar a moral do político, em virtude de a qualidade universalista da moral abstrair o sentido contingencial da existência humana. Para tanto, Schmitt retoma a ideia política secularizante, encarnada pelo Leviatã (1651) de Hobbes, a fim de combater o sentido que o conceito de secularização assume com o iluminismo. Tal sentido, também denominado por Hermann Lubbe de secularismo, apresenta-se à apreciação de Schmitt como moral universalizante, cujo escopo é banir a contingência do mundo e, consequentemente, negar o político. Certamente Lubbe concorda com Schmitt ao afirmar que a secularização de cunho iluminista, precisamente o secularismo, teria o sentido do "banimento de Deus da vida pública e privada e a deificação da natureza humana”. O secularismo, diz Lubbe, "surgiu a partir do iluminismo, recebendo então da revolução francesa um impulso rígido que foi adotado pelo liberalismo do século XIX" (Lubbe, 2003, p. 132).

A determinação do político, segundo a interpretação de Schmitt, advém da impossibilidade do caráter exorbitante dos conflitos provocados pelo fermento moral universalizante. Por isso, para o jurista, a efetiva secularização, racionalização ou humanização dos antagonismos só é possível por meio do reconhecimento dos antagonismos como algo existencial (Schmitt, 1997, p. 113). A condição de possibilidade do político é a neutralização da política teológica da moral cristã por meio da secularização do conceito teológico de inimizade. A partir daí, Schmitt considera possível não apenas discernir, mas também desconectar, pela neutralização, a intensidade política extrema proveniente de doutrinas teológicas moralizantes do âmbito político existencial da vida humana. Promovendo essa desconexão secularizante, cujo efeito livra o político do suporte moral absolutizante - esteio da democracia liberal -, o jurista pretende diluir o fundamento metafísico do liberalismo democrático, cuja expressão maior surge na sacralização universalizante do sujeito individual.

Diante do que foi até aqui exposto, caberia indagar como se procede à secularização do político. A alusão de Schmitt ao autor do Leviatã nos fornece uma pista relevante. Segundo ele, Hobbes

[...] não foi nem um grande matemático nem um grande físico, tampouco um filósofo das ciências naturais. Sua realização científica pertence inteiramente à philosophia practica. Ele percebeu que todo conflito entre uma competência espiritual-eclesiástica e uma competência secular-política se torna um conflito político no mesmo momento em que se eleva a uma 
questão de autoconservação (Selbstbehauptung); assim, o conflito não pode ser decidido por meio de distinções tão perspicazes entre espiritual, temporal e gênero misto (res mixtae) senão apenas formalmente através da resposta à pergunta formal: Quis judicabit?"(Schmitt, 2003a, p.166).

Devemos nos ater ao aspecto central que Schmitt assimilou dos ensinamentos de Hobbes: o filósofo inglês teria notado que, da perspectiva da Igreja romana, o maior poder seria sempre o poder espiritual. A competência para responder quem decide, quem interpreta, quem jurisdiciona, caberia sempre ao detentor do poder espiritual. Acredito que tal constatação não seja de modo algum trivial. Aliás, muito pelo contrário, pois a constituição de uma ordem jurídica dependeria sempre da determinação das distinções últimas a partir das quais poderia se distinguir entre direito e lei, amigo e inimigo, guerra e paz, crime e pecado. Uma leitura atenta da terceira e quarta partes do Leviatã de Hobbes revelam que a sua hermenêutica das Sagradas Escrituras pode ser sintetizada na insistente pergunta: de onde as Escrituras retiram sua autoridade? Subjacente a essa preocupação crucial residiria a indagação sobre quem decidiria sobre o que é sagrado ou profano, divino ou demoníaco, bondoso ou herético etc. Aqui o problema da pretensão do monopólio da decisão sobre autenticidade, verdade ou definição conceitual é uma questão eminentemente política de quem detém a autoridade. À secularização do político não basta a disposiçãoo de um poder qualquer, que, na acepção de Schmitt, não é outra coisa senão um instrumento técnico. Poder destituído de uma autoridade (espiritual no sentido intelectual) capaz de definir o que ele seja ou a que fim se destine é puro recurso técnico.

É imprescindível compreender que a existência de um agrupamento humano depende da autoridade que detém o monopólio das distinções últimas (poder espiritual), precisamente da determinação de quem é o inimigo a ser combatido. Tal poder espiritual, capaz de determinar quem ameaça a existência de uma coletividade humana, consiste numa decisão última, espiritual cujo caráter é, ao mesmo tempo, existencial. Mais ainda, tal questão - o monopólio espiritual do poder decisório - pertence ao político, na medida em que é uma questão existencial distinguir entre amigo e inimigo, guerra e paz, civil e combatente, sagrado e profano, verdade ou falsidade. A compreensão de que o maior poder corresponderia àquele pertencente à autoridade espiritual, precisamente o da decisão última (do juízo final ou do tribunal último), é para Schmitt a grande lição aprendida com seu professor Thomas Hobbes. A necessidade de transferir às mãos do domínio estatal tal espécie de decisão primária ou instância última decisória, a qual compete a distinção entre amigo e inimigo, indicaria impossibilidade de secularizar ou conferir visibilidade ao domínio político secular sem o monopólio da instância última de decisão. Não bastariam os meios legítimos de violência para a esfera secular do poder político, pois sua emancipação dependeria de uma instância última de decisão, cuja competência tradicionalmente pertencera ao poder espiritual. Conforme Schmitt:

[...] todas as distinções metafísicas, teológicas-morais, jusnaturalistas e canônicas-jurídicas da Igreja romana sempre foram, por fim, respondidas com o fato de que é ao poder espiritual, como poder supremo, que compete responder Quis Judicabit. Antes de tudo, a distinção de assuntos direta e indiretamente espirituais significava, do ponto de vista do resultado prático, que era o poder espiritual que decidia tão logo seu interesse existencial na questão concreta fosse forte o suficiente. $\mathrm{O}$ significado epocal de Thomas Hobbes consiste em ter reconhecido de forma conceitualmente clara o sentido puramente político da pretensão espiritual da decisão (Idem, pp. 166-167).

Os conflitos entre poder espiritual e temporal não só revelariam o caráter político de distinçōes, ideias e conceitos do poder espiritual, mas tornariam patente que ele é o poder mais importante, porque determina o sentido dos conceitos mais relevantes do político, como é caso do par conceitual amigo e inimigo. A esfera do político somente se torna visível a partir da estatização da decisão última, da sujeição do poder espiritual ao poder temporal. Aqui se torna claro que sem o controle do 
poder espiritual ou intelectual, entendido como determinação das distinçōes últimas, não é possível emancipar uma ordem política e governar as ações humanas. A lição do poder espiritual que Schmitt extrai de Hobbes é indispensável para o desenvolvimento do conceito do político como um critério heurístico de distinção do que seja político.

\section{O grau de intensidade do político}

O político diferenciar-se-ia da política por não se constituir numa substância, forma de governo ou conjunto de objetivos, mas num critério, uma medida que poderia ser observada na "distinção amigo inimigo que tem o sentido de designar um grau de intensidade extremo de ligação ou separação da associação ou dissociação" (Schmitt, 2002b, p. 27, grifo meu). Schmitt introduziu o critério do grau de intensidade na segunda edição de 1932 do Der Begriff des Politischen a fim torná-lo mais claro, o que não deixou de lhe render inúmeras críticas (Noack, 1996, pp. 118-119). A descrição do político como grau mais extremo de uma luta não significa que a distinção entre amigo e inimigo provoca uma inimizade absoluta ou uma guerra total. Muito pelo contrário, o político fundamenta-se na impossibilidade da radicalidade extrema dos conflitos. Para Schmitt, a secularização do político significa sua desconexão de uma moral teológica ou humanitária. A desteologização do político descortina uma esfera secularizada da inimizade existencial, livre de um fundamento moral que elevava o antagonismo ao grau mais extremo, tornando impossível a sua delimitação. $\mathrm{O}$ jurista parece extrair a referida medida da observação da intensidade máxima da radicalidade das guerras civil-religiosas europeias, que o domínio do reino secular conseguiu eliminar de seu interior. Em Behemoth or the long Parliament, Thomas Hobbes sugere um critério para aferir o grau de intensidade do antagonismo extremo dos conflitos religiosos que devastavam a Inglaterra:

Se no tempo, como no espaço, houvesse graus de alto e baixo, acredito firmemente que o mais alto dos tempos seria o que transcorreu entre os de 1640 e 1660 . Pois quem do topo, como da Montanha do Diabo, olhasse o mundo e observasse as ações dos homens, sobretudo na Inglaterra, descortinaria um panorama de todas as espécies de injustiças e de loucura que o mundo pôde proporcionar, e de como foram geradas pela hipocrisia e presunção - aquela, dobrada iniquidade, esta dupla loucura (Hobbes, 2001, p. 31, grifos meus).

Hobbes percebera que a insanidade das contendas civis e religiosas não era apenas provocada pelas armas convencionais visíveis, mas que as ideias, "distinções ininteligíveis" e conceitos também eram fatores que poderiam elevar ao extremo o grau de intensidade das lutas (Idem, p. 40). A intensidade política de ideias, conceitos, distinções poderia derivar de qualquer conteúdo, fosse ele teológico, moral, jurídico ou econômico. Hobbes identificou com tanta clareza as distinçôes políticas dos poderes indiretos ou invisíveis que chegou a exibi-las no frontispício de seu Leviatã (1651). A realidade concreta das lutas sangrentas entre os poderes espiritual e temporal que dilaceram a Europa teria demonstrado a extensão da letalidade exercida pelos conceitos e distinções do poder espiritual. Não é por acaso que Schmitt insiste neste ponto no seu trabalho sobre o filósofo inglês e comenta que além de "Hobbes ter reconhecido conceitos e distinçōes como armas políticas, [...] não há nenhum outro filósofo cujos conceitos tenham tido tanto efeito, ainda que, ao mesmo tempo, tivessem tanto impacto negativo sobre seu próprio pensamento". Assim, Schmitt revela a lição que extrai de Hobbes "na luta do grande professor contra todas as espécies de poder indireto". Exatamente nesse aspecto, prossegue o jurista, "concluímos hoje sua reconhecível e duradoura realização frutífera" (Schmitt, 2003a, pp. 130-131). Creio não haver dúvida quanto ao fato de Schmitt pretender continuar essa "duradoura realização frutífera": a luta secularizante contra poderes invisíveis que encobrem o sentido polêmico dos conceitos políticos da teoria do Estado moderno. Gunther Maschke relata que Carl Schmitt "foi durante sua vida inteira adversário de toda forma de potectas indirecta" (Maschke, 2003, p. 187).

A secularização, como luta contra os poderes indiretos ou invisíveis que se arrogavam o domínio 
político, seria um processo inacabado e jamais plenamente concluído para um pensamento comprometido com a situação concreta do presente. Nesse sentido, a democracia liberal seria o poder indireto a ser secularizado. Enquanto houver obscurecimento, negação ou confusão quanto à existência de conflitos entre seres humanos seria necessário secularizá-los ou torná-los visíveis. A guerra civil-religiosa não deve ser considerada como a lembrança de um terror que passou, mas deve ser encarada como conhecimento presente da potencialidade de um conflito extremo, cuja neutralização permite distinguir entre amigo e inimigo. Os escritos de Schmitt sobre Hobbes ${ }^{8}$ são a maior prova da convicção do jurista de que

[...] todo conhecimento histórico é conhecimento do presente, porque ele recebe sua luz e sua intensidade do presente e no sentido mais profundo serve ao presente, porque todo espírito somente é espírito presente nos disseram muitos desde Hegel e ninguém melhor que Benedetto Croce (Schmitt, 2002b, p. 79).

O sentido secularizante atribuído ao Leviatã de Hobbes é interpretado por Schmitt como a questão fundamental de seu tempo "presente": a secularização, a visibilidade da dimensão político-existencial da vida humana. A questão é, paulatinamente, identificada desde os seus primeiros trabalhos, passa a ser formulada e enfrentada de forma cada vez mais explícita. A investigação da oposição entre lei e decisão, direito e força, Estado e poder, nos primeiros estudos do autor, focalizava o problema da contingência que não só não poderia ser negado, como também seria uma condição de possibilidade para compreensão da estrutura da realidade concreta. No Der Begriff des Politischen, Schmitt busca mostrar que a negação do conflito pode elevar a contingência ao extremo, extrapolando o limite máximo do político. O reconhecimento da possibilidade do antagonismo extremo é a condição para restringi-lo.

Schmitt dedicou-se durante quase toda sua vida à secularização do político, cujo sentido se expressa no enfrentamento dos poderes invisíveis que buscam eclipsá-lo por meio de sua subordinação à moral, à economia, ao direito. A crença na técnica apresentar-se-ia sob a forma de uma religiosidade extrema, cuja fé cega se revelaria numa despolitização absoluta, o que intensificaria ainda mais os conflitos (Schmitt, 2002b, p. 94). O sentido atribuído à secularização por Schmitt certamente difere do apresentado no Leviatã de Hobbes, sobretudo, no que respeita ao inimigo a ser confrontado. A questão do "tempo presente" de Schmitt não exigiria mais combate ao poder eclesiástico presbiteriano ou aquele exercido por papas, bispos, falsos profetas que ameaçavam o domínio secular do poder político visível. A realidade concreta de Schmitt demandaria o combate às forças "apolíticas" que negam ou procuram recalcar o político. Certamente não caberia mais mostrar que o poder de excomunhão do papa era uma poderosa arma política capaz de mudar os rumos da política secular, determinando o inimigo do reino de Cristo. Cabe para Schmitt, por exemplo, elucidar que a imposição de embargos econômicos, a proibição da guerra, a conversão do inimigo em concorrente de negócios, a desmilitarização não deixam de apresentar um caráter político.

Segundo o jurista, os poderes espirituais apolíticos de hoje buscariam negar o político por meio de uma movimentação entre ética e economia. Desse modo, toda questão poderia ser subsumida ao conceito de propriedade privada, à ideia de progresso humanitário e moral, ao desenvolvimento dos meios técnicos. A confusão entre política, moral, economia e direito seria repleta de eufemismos e fórmulas de mitigar a real potencialidade de um antagonismo extremo entre os homens. Considero que a questão para qual Schmitt busca resposta não difere daquela de Hobbes quanto à necessidade de combater os poderes indiretos. $\mathrm{O}$ jurista alemão e o filósofo inglês disparam suas armas políticas, respectivamente, o Der Begriff des Politischen e o Leviatã, contra o obscurecimento do âmbito secular da esfera do político "ocasionado pelas desordens do tempo presente" (Hobbes, 1983, p. 410).

Da perspectiva de Schmitt, a promessa de banimento da guerra da vida humana seria um embuste observável nas falsas profecias secularizadas em forma de prognósticos, nas filosofias progressistas da história orientadas pela propaganda da felicidade da vida na Terra. O desiderato do conforto e de uma vida melhor seria assegurado pela supera- 
ção da política mediante a crença no progresso vindouro. A usurpação do político por meio da manipulação de outras formas de crença, alicerçadas em ideias "apolíticas", poderia ser percebida no caso da filosofia progressista da história forjada pela burguesia liberal. Ainda assim, permanece a questão: quem são os novos inimigos da teologia política e do conceito do político de Schmitt? À indagação responde o jurista: “os antigos inimigos, os poderes 'indiretos' da Igreja e de organizações de interesses, reaparecem neste século sob a forma moderna de partidos políticos, sindicatos, associaçōes, com uma palavra: 'os poderes da sociedade" (Schmitt, 2003a, p. 116). $\mathrm{O}$ problema de tais formas de organização social seria a impossibilidade de integrá-las no interior do sistema de representação parlamentar, o que excluiria minorias e deixaria de fora uma multiplicidade de interesses. Um dos problemas principais que o jurista depreende do século XIX decorre da interpenetração do Estado e da sociedade. Dessa fusão resultaria a perda das distinções, não sendo mais possível discernir com nitidez o Estado de outras associaçôes. O pluralismo social significaria a perda da unidade política, das distinções últimas determinadas pelo monopólio do poder político do Estado.

As formas do poder indireto diluiriam o político na economia, na organização técnica, na empresa, na autorregulamentação da vida social. Contra a sujeição do político ao econômico e ao domínio da moral da democracia liberal, Schmitt protesta:

[...] hoje não há nada mais moderno do que a luta contra o político. Americanos financistas, técnicos industriais, socialistas marxistas, e revolucionários anarco-sindicalistas se unem na exigência de que se elimine a falta de objetividade do domínio político sobre a objetividade da vida econômica. Somente devem existir tarefas técnicas organizacionais e econômicas, mas não mais problemas políticos (Schmitt, 2004, p. 68; 1950, p. 38).

Hobbes foi reverenciado por Schmitt como "o pioneiro da secularização", cujas ideias contribuíram para o surgimento do Estado moderno europeu. Todavia, afirma que o autor inglês "concomitantemente escancarou o contraste através da reserva de crença na interioridade privada que abriu o caminho para novos e perigosos modos e formas de poderes indiretos" (Schmitt, 2003a, pp. 140 e 127, grifo meu). A porta deixada aberta por Hobbes à crença privada tornar-se-ia o fermento da destruição do Estado pela via de seu próprio interior. A reserva de crença "resultou no germe letal que destruiu pelo interior o poderoso Leviathan e abateu o Deus mortal" (Idem, p. 86). Não demoraria muito para a distinção entre confissão e fé, exterior e interior se converter em uma das formas de oposição entre poderes visíveis e invisíveis, entre público e privado até o momento em que a reserva de crença, até então situada num segundo plano, invertesse a situação de poder. Daí em diante o poder invisível proveniente do espaço secreto privado e associado à burguesia liberal ascendente passava a subjugar, de forma indireta, o espaço público do político (Idem, pp. 88 e 93). A inversão pela qual o espaço secreto do privado passa a se sobrepor ao público provocaria o esvaziamento do espaço público do poder, gerando um problema de representação. Para Schmitt,

[...] se o poder público realmente só quiser ser público, se o Estado e a confissão empurram a fé interior para o "privado", então a alma de um povo se dirige para o "caminho do secreto" que leva ao interior. Assim cresce a contraforça do silêncio e da tranquilidade. No momento em que a distinção entre interior e exterior é reconhecida, a superioridade do interno sobre o externo, e, portanto, a do privado sobre o público já é, no seu âmago, coisa decidida. Um poder e força públicos podem ser completa e enfaticamente reconhecidos e lealmente respeitados, mas somente como poder público e externo é oco e já sem vida a partir do interior [entseelt] (Idem, p. 94).

A divisão interna do Estado em interno e externo levaria à polarização: entre a moral liberal e a política absolutista, entre a divisão dos poderes e a indivisibilidade do poder soberano, entre a verdade parlamentarista e o executivo decisionista, entre pluralismo social e unidade política. "Quem se envolve com a contraposição entre interior e ex- 
terior em geral já reconheceu com isso, por fim, a superioridade do interno sobre o externo, do invisível sobre o visível, do silêncio sobre audível [Lautem], do outro mundo [Jeinseits] sobre este mundo [Jenseits]" (Idem, p. 95). Ora, aqui se verificaria a impossibilidade da forma política de um poder estatal, "pois não existe Estado sem representação" (Idem, p. 206).

A representação política inexiste no interior do espaço privado, pois representação "somente pode ocorrer na esfera do público. Não há nenhuma representação que aconteça em secreto e a sós; nenhuma representação que seja 'assunto particular'”. Assim, "todos os conceitos e ideias que essencialmente fazem parte da esfera do privado, do direito privado e do unicamente econômico são excluídos; portanto, gestão de negócios, percepção e representação [Vertretung] de interesses privados etc.”. Do ponto de vista político, o Estado liberal age como uma pessoa "invisível", pois serve aos interesses econômicos como os de uma empresa representante dos interesses particulares (Schmitt, 2004, pp. 44 e 66). A representação política do Estado tornar-se-ia inviável, sofreria uma distorção indicada também por conceitos e ideias cuja confusão se explicaria pelo uso da semântica conceitual do direito privado para tratar de coisas públicas. Os direitos particulares e interesses privados subordinariam gradativamente o direito público. A perda de referência a algo externo, supraindividual, estaria relacionada com ausência da "unidade política de um povo".

A representação de uma unidade política somente seria possível pela mediação de uma ideia transcendente, pois no plano empírico inexiste a unidade devido à sua pluralidade e relativismo imanentes. A ideia de unidade de um povo somente ganharia forma na pessoa de um soberano e jamais na impessoalidade da lei, cuja abstração e generalidade velariam o caráter pessoal e a responsabilidade política de quem realmente toma as decisões. Seria uma característica típica do poder indireto ou invisível da burguesia liberal fazer política na segurança do espaço privado por meio da transferência de responsabilidade à lei, ao legislador, à moral, à opinião pública. $\mathrm{O}$ parlamento retratado como espaço fechado em que teriam lugar discursos e sessões intermináveis seria o palco de um poder indireto.
A sustentação de seu caráter representativo residiria na crença de que suas sessões secretas, acordos e deliberaçôes reservadas, comitês, comissões parlamentares de inquérito seriam atividades públicas (Schmitt, 2003b, p. 208). A ausência de uma forma jurídica adequada à representação encontraria suas raízes na substituição do absoluto que tinha lugar na pessoa do soberano pelo absoluto do indivíduo particular. Esse deslocamento do absoluto para o assento privado do sujeito individual, relativo e desvinculado de referências heterônomas, seria o lugar onde se iniciaria a fragmentação da experiência política da forma jurídica e do princípio de representação. $\mathrm{O}$ sentido absoluto não deixou de existir a partir do momento em que a burguesia emergente do espaço privado tomou o centro do poder. A diferença é que seu acento passa a residir nas coisas privadas, nas propriedades particulares, desencadeando-se uma crescente coisificação. Vale elucidar que, da perspectiva de Schmitt, um caráter sagrado ou uma reminiscência teológica se conserva quando uma crença se torna absoluta. Ao discutir a noção de representação do liberalismo burguês, o jurista comenta que: "nada neste sistema é representativo, tudo é uma coisa privada”. A origem do problema de representação derivaria da liberdade de crença religiosa. Do ponto de vista de Schmitt, a religião poderia se constituir em uma ameaça, pois se o religioso estiver no espaço privado, o privado se tornaria uma coisa religiosamente sagrada:

[...] a propriedade privada é então sagrada exatamente por ser uma coisa privada. Esta união, que até agora quase não se tornou consciente, explica o desenvolvimento sociológico da sociedade moderna europeia. [...] Nela também há uma religião: a religião do privado [...] considerada historicamente a "privatização", inicia-se no fundamento, na religião. $\mathrm{O}$ primeiro direito individual, no sentido da ordem social burguesa, foi o direito de liberdade religiosa (Schmitt, 1984, pp. 48-49).

A partir daí seria possível entender como se formam as "representaçôes de imanência" que emanam da crença que eleva o espaço privado do indivíduo a uma instância absoluta. Schmitt investiga a submis- 
são do Estado e da política à moral liberal, buscando entender a despolitização a partir dos pressupostos metafísicos que conduziriam ao esvaziamento da substância política da realidade por meio de categorias econômicas e noções do direito privado. A compreensão das premissas do liberalismo burguês poderia ser observada na analogia de seus conceitos, ideias e forma de organização política com o movimento romântico do século XIX. A analogia descortinaria a relação entre a cultura romântica do século XIX e as instituições políticas e sociais do liberalismo. A declaração de Schmitt segundo a qual "o portador do movimento romântico é a nova burguesia" sugere que as ações e, sobretudo, as motivações liberais se orientariam pela crença em ideais do romantismo (Schmitt, 1998, p. 14). O problema, entretanto, do romantismo seria encontrar uma definição de suas características, pois um de seus traços fundamentais seria percebido na sua indefinição atribuída à sua existência labiríntica, à sua falta de forma e representação (Idem, p. 10). Sua carência de forma evidenciar-se-ia numa peculiar capacidade de dissolver liames, desatar vínculos com algum ponto ou direção fixada pela realidade.

Um comportamento tipicamente romântico jamais se guiaria por uma orientação segura, mas se levaria pela ocasião de transformar elementos externos em possibilidade de experiência e de consumo subjetivo. A postura romântica, orientada pela ocasionalismo, desmancharia todo nexo de causalidade da realidade, convertendo tudo num lirismo. O movimento romântico encontraria um de seus núcleos centrais na esteticização, que poderia ser compreendida como uma forma de privatização ou esvaziamento das qualidades ou substâncias da realidade, levando à dissolução de referências externas, vínculos de causalidade, pontos de fixação e fatores de duração. A atitude romântica seria retratada pela occasio, isto é, a conversão de tudo numa ocasião, numa oportunidade para o sujeito romântico, cuja postura seria subjetivar o que é lhe exterior. O espaço de experiência da realidade seria uma fonte inesgotável de possibilidades a serviço do sujeito romântico. A ocasião seria um acúmulo de possibilidades sem fim (Idem, p. 79). Aí ressurge o problema, tratado nos trabalhos de juventude de Schmitt, da elevação da contingência que culmina no niilismo, numa imagem de mundo ilimitado, sintetizada na noção romântica do ludus globi (Idem, p. 111). A sujeição do mundo ao acúmulo ilimitado de possibilidades incidiria no niilismo, pois num universo em que tudo é uma ocasião nada ou nenhuma possibilidade se torna realidade, pois somente a decisão pode reduzir as possibilidades e conferir uma forma à realidade. A indecidibilidade ou suspensão da decisão pelo ocasionalismo seria um drama romântico interminável que poderia ser observado nas conversações infindáveis no parlamento da burguesia liberal. A atitude do sujeito romântico, retratada como subordinação do mundo à mera ocasião, encontraria ressonância na elevação do indivíduo liberal à instância absoluta da ordem social e política. Romantismo seria, conforme a interpretação de Schmitt, ocasionalismo subjetivado e encontraria manifestação análoga no indivíduo liberal burguês, incapaz de conferir forma política à realidade a partir da universalização do espaço privado.

\section{Conclusão}

A secularização é sempre um processo inacabado. A dimensão secularizada - existencial do político - apresenta-se como algo intolerável às doutrinas do Estado de cunho democrático-liberal, devido à inteligibilidade dos antagonismos entre seres humanos. Schmitt pretende por meio de seu conceito de secularização expor os riscos da democracia liberal ao revelar que a despolitização ou a negação da forma mais extrema da contingência, isto é, a dos antagonismos humanos, eleva os níveis de instabilidade política. A subsunção da realidade a representaçôes de imanência às normas jurídicas e leis do mercado não só oculta a decisão política soberana, mas também transfere a responsabilidade decisória para uma entidade abstrata e impessoal: o governo da lei. A secularização operada por Schmitt pretende revelar a hipóstase do deslocamento liberal da responsabilidade do agir político humano, concreto e personalístico para impessoalidade da norma jurídica abstrata e genérica. O político, compreendido como o inexorável caráter contingente da vida humana, condicionada à finitude e à inabalável possi- 
bilidade de conflito existencial não pode ser negado por uma simples razão: a negação da contingência ou dimensão existencial dos conflitos eleva seus níveis, pois a contingência não poder ser eliminada da vida humana, mas apenas reduzida.

\section{Notas}

1 De acordo com o autor, conceitos políticos precisam ser compreendidos em conformidade com o seu sentido histórico, precisamente a partir uma situação histórica específica que se refere sempre a um antagonismo concreto. Isso significa que os conceitos políticos são ininteligíveis fora da situação concreta de conflito que constitui seu núcleo semântico. Desse ponto de vista, se porventura nos furtamos à compreensão do sentido histórico concreto do antagonismo, os conceitos políticos "se convertem em abstrações vazias" (Schmitt, 2002b, pp. 30 e 31).

2 Todos os trechos de livros citados neste trabalho, publicados em alemão e constantes da bibliografia, foram traduzidos por mim.

3 O termo secularismo (Säkularismus) é empregado por Hermann Lübbe no livro Säkularisierung. Geschichte eines ideenpolitischen Begriffs [Secularização. História de um conceito político de ideia].

4 O caráter transcendente do político revela-se no fato de os antagonismos existenciais (dimensão do político) não poderem ser subordinados a nenhum conjunto de regras, sejam elas morais, jurídicas ou econômicas. $\mathrm{O}$ político transcende a qualquer normatização cuja generalização oculte a dimensão existencial do conflito.

5 Esta passagem é extraída por Schmitt do trabalho $L a$ Repéticion da autoria de Kierkegaard (1997, p. 66).

6 O conceito de Deus teísta e deísta é, respectivamente, compreendido por Schmitt como a representação de duas diferentes imagens que se opõem: a primeira revela um Deus pessoal que cria e governa o mundo; a segunda retrata um Deus impessoal que, a despeito de ter sido o criador do mundo, nele não intervém. Tais concepções de Deus correspondem, respectivamente, a imagens de transcendência e imanência, que encontram sua estrutura análoga na organização social e política cujo soberano é uma autoridade pessoal capaz de intervir na realidade concreta, e um soberano impotente, incapaz do governar (Schmitt, 2004, pp. 51-55).

7 Emprego desontologização no sentido de privatização ou esvaziamento das qualidades da realidade do ser, mediante um processo intenso de subjetivação ou remissão do sujeito individual para o interior de seu pensamento. A desontologização de um sujeito soberano, pessoal e supraindividual, dotado de autoridade, teria ocorrido segundo Schmitt no século XVII com "reviravolta cartesiana". Vale salientar que tal processo conduz a uma fuga do ser para dever ser, e "quanto mais se torna puramente normativista, conduz a uma separação cada vez mais explícita entre a norma e a realidade, entre ser e dever ser, entre regra e conjunto de fatos concretos" (Schmitt, 1993, p. 15).

8 O sociólogo alemão Helmut Schelsky observa "que Hobbes não era apenas do ponto de vista científico-acadêmico o autor 'predileto' de Carl Schmitt, mas que Schmitt" é o “"Hobbes alemão do século XX” (Schelsky, 1981, p.5).

\section{BIBLIOGRAFIA}

FERREIRA, Bernardo. (2004), O risco do politico: crítica ao liberalismo e teoria politica no pensamento de Carl Schmitt. Belo Horizonte, Editora da UFMG.

KIERKEGAARD, Soren. (1997), La repetición. Buenos Aires, Juan Ventura Squivel.

LUBBE, Herman. (2003), Säkularisierung. Geschichte eines ideenpolitischen Begriffs. 3 ed. Munchen, Alber Studienausgabe.

LUHMANN, Niklas. (2002), Die Religion der Gesellschaft. Frankfurt am Main, Suhrkamp.

MASCHKE, Gunter. (2003), “Zum 'Leviathan' von Carl Schmitt". In: Carl Schmitt, Der Leviathan in der Staatslehre des Thomas Hobbes. Sinn und Fehlschlag eines politischen Symbols. 3 ed. Stuttgart, Klett-Cotta, p p. 179-244.

NOACK, Paul. (1996), Carl Schmitt. Eine Biographie. Frankfurt am Main, Ullstein.

PREUSS, Ulrich. K. (2003), Krieg, Verbrechen, Blasphemie. Gedanken aus dem alten Europa. Berlim, Klaus Wagenbach.

SCHELSKY, Helmut. (1981), Thomas Hobbes: eine politische Lehre. Berlim, Duncker \& Humblot.

SCHMITT, Carl. (1950), Donoso Cortés in gesamteuropäicher Interpretation. Köln, Greven Verlag. (1984), Römischer Katholizismus und politische Form. Berlin, Klett-Cotta [reimpressão da 2a edicão de 1925]. 
(1993 [1934]), Uber die drei Arten des rechtwissenschaftlichen Denkens. 2 ed. Berlim, Duncker \& Humblot. (1996 [1923]), Die geistesgeschichtliche Lage des heutigen Parlamentarismus. 8 ed. Berlim, Duncker \& Humblot. (1997), Der Nomos der Erde im Völkerrecht des Jus Publicum Europeum. Berlin, Dunckler \& Humblot. (1998), Politische Romantik. Berlim, Duncker \& Humblot [reimpressão da $2^{\mathrm{a}}$ ed. 1925].

(2002a), Das Zeitalter der Neutralisierungen und Entpolitisierungen in der Begriff des Politischen. 7 ed. Berlim, Duncker \& Humblot.

. (2002b), Der Begriff des Politischen. Text von 1932 mit einem Vorwort und drei Corollarien. 7 ed. Berlin, Duncker \& Humblot [5 ${ }^{\text {a }}$ reimpressão da edição de 1963]. . (2003a), Der Leviathan in der Staatslehre des Thomas Hobbes. Sinn und Fehlschlag eines politischen Symbols. 3 ed. Stuttgart, KlettCotta.

(2003b), Verfassungslehre. Berlim, Duncker \& Humblot. (2004), Politische Theologie. Vier Kapitel zur Lehre von der Souveränität. 8 ed. Berlim, Duncker \& Humblot.

STRAUSS, Leo. (1998), "Anmerkung zu Carl Schmitt, Der Begriff des Politischen”. In: Heinrich Meier (org.), Carl Schmitt, Leo Strauss und "der Begriff des Politischen". Zu einem Dia$\log$ unter Abwesenden. Stuttgart, J. B. Metzler, pp. 97-125.

HOBBES, Thomas. (1983), "Leviatã ou matéria, forma e poder de um estado eclesiástico e civil", in: Thomas Hobbes. 3 ed., São Paulo, Abril Cultural (col. Os Pensadores). (1985 [1651]), Leviathan. Londres, Penguin.

(1990), Behemoth; or, The long Parliament. Chicago, The University of Chicago Press.

(2001). Behemoth ou o longo parlamento. Belo Horizonte, Editora da UFMG. 


\section{A DESPOLITIZAÇÃO DA DEMO- CRACIA LIBERAL NO PENSAMEN- TO DE CARL SCHMITT}

\section{Pedro Villas Bôas}

Palavras-chave: Despolitização; Democracia liberal; Secularização; Contingência; Estado.

A secularização de teorias do Estado moderno ainda é um processo inacabado. A despolitização promovida pela democracia liberal priva as concepçóes do Estado moderno de seu conceito de soberania ao reduzir o político ao âmbito da moral, do direito e da economia. O conceito de secularização, empregado por Carl Schmitt, permite desvelar as concepções de imanência que ocultam as açôes políticas concretas revestidas com o manto do governo da lei. Para Schmitt, a secularização do político confere visibilidade aos antagonismos existenciais humanos escamoteados pela democracia liberal.

\section{DEPOLITIZATION OF LIBERAL DEMOCRACY IN THE THOUGHT OF CARL SCHMITT}

Pedro Villas Bôas

Keywords: Depolitization; Liberal democracy; Secularization; Contingency; State.

The secularization of State theories is still an unfinished process. The depolitization conducted by the liberal democracy deprives the conceptions of modern State from its concept of sovereignty as it reduces the political to moral, law, and economy only. The concept of secularization used by Carl Schmitt unveils the conceptions of immanence which conceals the concrete political actions dressed in the cloak of the rule of law. For Carl Schmitt, the secularization of the political confers visibility to the human existential antagonisms which are usurped by the liberal democracy.

\section{LA DÉPOLITISATION DE LA DÉMOCRATIE LIBÉRALE DANS LA PENSÉE DE CARL SCHMITT}

Pedro Villas Bôas

Mots-clés: Dépolitisation; Démocratie libérale; Sécularisation; Contingence; État.

La sécularisation des théories de l'État moderne demeure un processus inachevé. La dépolitisation menée par la démocratie libérale prive les conceptions de l'État moderne de leur concept de souveraineté en réduisant la politique à son aspect moral, de droit et d'économie. Le concept de sécularisation, employé par Carl Schmitt, permet de dévoiler les concepts d'immanence qui cachent les actions politiques concrètes revêtues de l'autorité du gouvernement de la loi. Pour Schmitt, la sécularisation de la politique donne une visibilité aux antagonismes existentiels humains que la démocratie libérale se charge de cacher. 